\title{
Principal Leadership in the Implementation of Effective School Management
}

\author{
Cucun Sunaengsih ${ }^{\bowtie 1}$, Mayang Anggarani $^{2}$, Mia Amalia $^{3}$, Silmaulan Nurfatmala $^{4}$ \& Syifa Diana Naelin 5 \\ 1,2,3,4,5 Pendidikan Guru Sekolah Dasar, Universitas Pendidikan Indonesia, Bandung, Indonesia \\ $\triangle$ cucunsunaengsih@upi.edu
}

\begin{abstract}
This research aims at describing the implementation of effective school management based on the principal leadership in one of Public Primary Schools in Sumedang Regency, West Java, Indonesia. The principal who implemented effective school management had the potential to produce high-achieving young generation because the school scope could optimize its function as an educational institution that carried out economic, humanitarian, social, political, cultural, and educational functions. One aspect that could support the implementation of effective school management was the principal leadership in making decisions, communicating, directing and developing the staff, solving problems and evaluating school activities. The data were collected through questionnaires, interviews and documentation studies. Furthermore, the results proved that the principal leadership was one of the main factors in implementing effective school management in terms of technology, school culture, information systems, and organizations.
\end{abstract}

Keywords: effective school management, leadership, principal.

How to Cite: Sunaengsih, C., Anggarani, M., Amalia, M., Nurfatmala, S., \& Naelin, S. (2019). Principal Leadership in the Implementation of Effective School Management. Mimbar Sekolah Dasar, 6(1), 79-91. doi:http://dx.doi.org/10.17509/mimbar-sd.v6i1.15200.

\section{INTRODUCTION School management is} one factor that determines the quality of the education (Lessa, Spier and Felipe, 2018), since it indirectly determines the effectiveness of the curriculum, learning facilities and infrastructure, time and learning process (Salmagundi, 2015). Seen from management perspective, effective schools seek optimal utilization of all school components (Kompri, 2017).

As a formal educational institution, schools are required to produce graduates who have academic abilities, skills, attitudes and mentality, and competent personalities so that students have competitiveness after they graduate from an institution (Al-Momani, Allouh and Alhomran, 2012). Schools that have strong principal leadership are predicted to be able to develop effective school management, because they are supported by various aspects, such as the application of technology, school culture, information systems and developed organizations. However, in reality not all principals are able to run strong leadership-based schools (Brooks, 2005).

Principal leadership in school
management implementation is
considered important as it could ease
sharing work activities. A well-organized
school environment involves several


Cucun Sunaengsih et.al., Principal Leadership in the Implementation of Effective School...

elements, including the principal, teachers, employees and students. Furthermore, good organization creates tasks and responsibilities divisions that were evenly distributed to facilitate the work process in achieving shared goals (Suryosubroto, 2010). Close cooperation and involvement between principals, teachers, employees and students through their respective responsibilities would improve the school quality (Umaedi, 1999).

Leadership is an essential part in achieving the desired school quality (Chow, Ph and Learning, 2013). Schools will progress if they have a visionary school principal, high integrity in carrying out quality improvements, and good managerial skills (Krug, 2004). The key to the success of the principal as a supervisor is to re-interpret the meaning of supervision (Suryosubroto, 2010). Supervision is an activity that determines the situation and conditions that are essential for achieving an educational goal. There are several goals of educational supervision such as helping to improve the quality of teachers, and helping principals adjust the appropriate programs to improve business in producing quality graduates (Pidarta, 2009). Successful division of tasks in schools also depends heavily on the ability of the principal to perform his leadership. In implementing the leadership, the principal can determine school management according to the organizational climate found in the school (FIP-UPI Education Science Development Team, 2007).
Therefore, the principal is tasked with fostering the institution to achieve the educational goals that has been set together by always directing and coordinating with all parties involved in all activities. Principals in occupying their duties as managers should have basic functions and skills of a manager. The basic function that should be owned by the principal as a manager is a function in planning, organizing, mobilizing and controlling school management (Bergeron, 2011). While the basic skills that should be mastered are skills in building concepts in planning, establishing human relations by building good communication and technical skill is performing tasks directly in the field especially when finding a problem, this skill is often used to control subordinates in the field (Pidarta, 2009). In addition, school management productively becomes a support for the birth of a generation of high achievers and the application of school culture that adapted to the times. This attitude is shown by the principal sensitivity to all forms of reformation that could support the education reformation (Smith, 2013). Such school culture is closely related to the vision of the principal. Principal who has a vision to face the future challenges would be more successful in building a school culture (Kwek, Lau and Tan, 2010). The results of the achievements can be built through the school culture that optimizes school activities, such as through extracurricular activities. With extracurricular activities, school could also 
focus on the fields they want to develop, which in turn could be an advantage (Asmani, 2014).

The concept of effective schools could be pursued through effective and efficient organizational procedures implemented by school principal in school organization managerial. The effective managerial is characterized by the functioning of a good organizational structure in order to meet schooling services (Ibrahim, 2016). A research states that the principal leadership style could determine the performance of the teacher under their leadership (Nurbaya, Harun, \& Djaelani, 2015). Adequate organizational capacity created a good bureaucratic system. Conversely, if the principal leadership could not work well, it would undermine the performance of the organization, which indirectly would become a weakness (Satriadi, 2016). Apart from the principal leadership which was inherently personal, there are other things that supported the creation of effective school management that involves the technology in school, a well-integrated information system, and school culture as bridges to create good relationships between principal, teachers, employees, students and communities around the school environment (Brooks, 2005).

The aforementioned research results show that the effective school management mostly started with the principal managerial abilities in all activities conducted and the optimization of technology, information systems, and culture applied in schools as supporting aspects in achieving educational goals. However, some of the results had not elaborated the things that influenced the way the principal led and the application of involvement that support the realization of effective school management. Hence, this research generally aims at determining the principal leadership application to effective school management as seen from the dimensions of concept, design, requirements, procedures, impacts, technology, culture, organization, information system quality, and leadership quality. This research is essential because it involved the principal policy in organizing all components of the school to create an effective school. The component of the school consisted of students, teachers, parents, and the surrounding community. The way school principal manage schools will be more productive, which in turn would produce a generation of high achievers and the culture applied in schools that would be the balancing factor in establishing the vision and mission to achieve effective school management targets (Dreiss et al., 2017).

\section{METHODS}

This research was conducted using a qualitative method and survey approaches, which was done in a natural setting. Natural research is not something intentionally made such as experiments and formal interviews that would be a source of data (Komariah and Satori, 
Cucun Sunaengsih et.al., Principal Leadership in the Implementation of Effective School...

2010). The survey approach was considered suitable because it aims at examining the behavior and views the ordinary routine and natural activities. In addition, the subjects' behavior toward themselves, others and the surrounding were then analyzed in order to find the reasoning behind (Mulyana, 2010). This research views social reality as something intact, complex, dynamic, full of meaning, and the symptoms had an interactive relationship (Rahmat, 2009). Therefore, this research was conducted on objects that were not manipulated and the research also did not affect the dynamics of the object. Furthermore, it was conducted in a
Public Primary Schools in Sumedang Regency involving 15 teachers as the subjects. Teachers were selected as the main research subjects because they are the largest population who were directly involved in the implementation of effective school management. However, the samples were chosen randomly to be in accordance with the approach used to retrieve the information. Furthermore, the instruments in were questionnaires and interview guidelines. The following is a data collection grid adapted from various theories (Krug, 2004; Kwek, Lau and Tan, 2010):

Table 1. Data Collection Grid.

\begin{tabular}{|c|c|c|c|c|c|}
\hline No & Variable & Indicator & Sub. Indicator & $\begin{array}{l}\text { Data } \\
\text { Source }\end{array}$ & Technique \\
\hline \multirow[t]{8}{*}{1.} & \multirow[t]{8}{*}{ Leadership } & \multirow[t]{3}{*}{$\begin{array}{l}\text { School } \\
\text { Making }\end{array}$} & $\begin{array}{l}\text { The principal involves } \\
\text { the teachers in every } \\
\text { decision making }\end{array}$ & \multirow[t]{3}{*}{ Teacher } & \multirow[t]{3}{*}{ Questionnaire } \\
\hline & & & $\begin{array}{ll}\text { The principal does } \\
\text { not involve the } \\
\text { teachers in any } \\
\text { decision making }\end{array}$ & & \\
\hline & & & $\begin{array}{l}\text { The principal make } \\
\text { the teachers aware } \\
\text { of the school } \\
\text { program plan }\end{array}$ & & \\
\hline & & \multirow[t]{2}{*}{ Communication } & $\begin{array}{l}\text { The principal is } \\
\text { friendly to the } \\
\text { teachers }\end{array}$ & \multirow[t]{2}{*}{ Teacher } & \multirow[t]{2}{*}{ Questionnaire } \\
\hline & & & $\begin{array}{l}\text { In making decisions, } \\
\text { the principal respects } \\
\text { each teachers' } \\
\text { opinion }\end{array}$ & & \\
\hline & & \multirow[t]{3}{*}{$\begin{array}{l}\text { Staff Directing and } \\
\text { Development }\end{array}$} & $\begin{array}{l}\text { The principal helps to } \\
\text { develop professional } \\
\text { abilities through } \\
\text { further education, } \\
\text { training, and seminars }\end{array}$ & \multirow[t]{3}{*}{ Teacher } & \multirow[t]{3}{*}{ Questionnaire } \\
\hline & & & $\begin{array}{l}\text { The school principal } \\
\text { becomes tutor for the }\end{array}$ & & \\
\hline & & & $\begin{array}{l}\text { teachers to get } \\
\text { achievement }\end{array}$ & & \\
\hline
\end{tabular}




\begin{tabular}{|c|c|c|c|c|c|}
\hline No & Variable & Indicator & Sub. Indicator & $\begin{array}{l}\text { Data } \\
\text { Source }\end{array}$ & Technique \\
\hline & & School Evaluation & $\begin{array}{lr}\text { Recognition } & \text { and } \\
\text { appreciation } & \text { of } \\
\text { teachers } & \\
\text { performance } & \end{array}$ & \multirow[t]{2}{*}{ Teacher } & \multirow[t]{2}{*}{ Questionnaire } \\
\hline & & & $\begin{array}{l}\text { The principal regularly } \\
\text { evaluates the } \\
\text { teachers } \\
\text { performance of and } \\
\text { employees }\end{array}$ & & \\
\hline & & Problem Solving & $\begin{array}{l}\text { When problems } \\
\text { arises, the school } \\
\text { principal conducts } \\
\text { deliberations to } \\
\text { resolve them }\end{array}$ & Teacher & Questionnaire \\
\hline & & \multirow[t]{3}{*}{$\begin{array}{l}\text { Principal Integrity } \\
\text { Vision and Mission }\end{array}$} & $\begin{array}{ll}\text { The principal can } & \begin{array}{l}\text { can } \\
\text { estimate }\end{array} \text { future } \\
\text { school needs } & \end{array}$ & \multirow[t]{3}{*}{ Teacher } & \multirow[t]{3}{*}{ Questionnaire } \\
\hline & & & $\begin{array}{l}\text { The principal } \\
\text { determines the ideals } \\
\text { and goals to be } \\
\text { achieved by the } \\
\text { school }\end{array}$ & & \\
\hline & & & $\begin{array}{l}\text { The principal provides } \\
\text { guidance to the } \\
\text { teachers }\end{array}$ & & \\
\hline \multirow[t]{5}{*}{2} & \multirow[t]{5}{*}{$\begin{array}{l}\text { Effective } \\
\text { School } \\
\text { Management }\end{array}$} & \multirow[t]{2}{*}{ Technology } & $\begin{array}{l}\text { The use of } \\
\text { technology in the } \\
\text { learning process }\end{array}$ & \multirow[t]{2}{*}{ Principal } & \multirow[t]{2}{*}{ Interview } \\
\hline & & & $\begin{array}{lr}\text { The role of } \\
\text { technology } & \text { in } \\
\text { developing } & \text { the } \\
\text { performance } & \text { of } \\
\text { school personnel } & \end{array}$ & & \\
\hline & & Culture & $\begin{array}{l}\text { School culture has } \\
\text { been routinely } \\
\text { carried out by all } \\
\text { school elements }\end{array}$ & Principal & Interview \\
\hline & & Information System & $\begin{array}{l}\text { Management of } \\
\text { information resources } \\
\text { in schools }\end{array}$ & Principal & Interview \\
\hline & & Organization & $\begin{array}{l}\text { Organizing teachers } \\
\text { performance }\end{array}$ & Principal & Interview \\
\hline
\end{tabular}

In accordance with qualitative research procedures, data analysis was conducted starting from displaying, presenting the data and drawing conclusions. Data analysis was used to collect data and information from the survey results related to the principal leadership in the implementation of effective school management in one of Public Primary Schools in Sumedang Regency.

\section{FINDINGS}

The principal had a vision to develop teacher professionalism through training. It 
Cucun Sunaengsih et.al., Principal Leadership in the Implementation of Effective School...

was in accordance with government policy in Law No. 14 of 2005 concerning Teachers and Lecturers. This was one of the efforts made by the principal as a school leader to improve the quality of their subordinates, especially teachers. The efforts made were involving teachers in cluster activities, PKG, seminars, workshops and other coaching seminars. One of the principal's visions to achieve effective school management that strives to be productive was by instilling confidence through the experience of religious teaching, gradually completing learning facilities and infrastructure, and optimizing the learning process. The culture that was applied by the principal was outlined by optimizing extracurricular activities. It was done by maintaining the talents, interests and potential of students and optimizing the community participation through the school committee.

Furthermore, the school principal had tried to carry out his leadership strongly in the implementation of effective school management. This could be seen by the vision made by the principal who was always oriented towards improving the quality of schools by improving the quality of teachers and other education personnel. The principal leadership style, which was giving rewards and motivation to the teacher, became an added value of the principal's managerial abilities, since giving motivation to teachers is considered important. However, there was also an obstacle that was often faced by principal. This obstacle arose when the principal and teacher could not respect each other for their performance. Motivation given by principal was in the form of encouragement such as praises or incentives, depending on the type of achievement made. Motivation is usually closely related to the goals, why it is desired (motives), and the steps to take in achieving the goals (processes) that have been determined (Mulyasa, 2013). By giving motivation, the principal hoped the teachers be able to pursue the best possible achievements.

Moreover, it was related to the applied curriculum, the 2013 Curriculum, which is oriented towards developing potential students. This certainly required the principal and teacher to provide the best performance in performing the task, so that the school could adjust to the changing environment and become a superior school in the community. Besides, not only being a superior school in the surrounding community, it could also generate achievement to compete with other schools in West Java. In addition, the results obtained by students through their achievements could have an effect on school accreditation, so that schools could continue to get an $A$ and maintain it.

Another managerial ability that the principal should have was to empower existing facilities and infrastructure because it was impossible for schools to do activities if they were constrained by 
facilities and infrastructure. However, schools should strive to optimize school performance, functions, and responsibilities through existing facilities and infrastructure. This was the responsibility of the principal, although the facilities and infrastructures were limited, such as limited technology that hampered the learning process and the below average information system due to the school location, it did not dampen the motivation to maximize the use of the existing facilities. Based on the data processing, the following were the results of data collection in accordance with the instrument specified:

Table 2. Data Collection Result.

\begin{tabular}{|c|c|c|c|c|}
\hline No & Variable & Indicator & Sub. Indicator & Conclusion \\
\hline \multirow[t]{12}{*}{1} & \multirow[t]{12}{*}{$\begin{array}{l}\text { Principal } \\
\text { Leadership }\end{array}$} & \multirow[t]{3}{*}{$\begin{array}{ll}\text { School Decision } \\
\text { Making }\end{array}$} & $\begin{array}{l}\text { The principal involves } \\
\text { the teachers in every } \\
\text { decision making }\end{array}$ & \multirow[t]{3}{*}{ Teachers agreed } \\
\hline & & & $\begin{array}{l}\text { The principal does not } \\
\text { involve the teachers in } \\
\text { any decision making }\end{array}$ & \\
\hline & & & $\begin{array}{l}\text { The principal make the } \\
\text { teachers aware of the } \\
\text { school program plan }\end{array}$ & \\
\hline & & \multirow[t]{2}{*}{ Communication } & $\begin{array}{l}\text { The principal is friendly } \\
\text { to the teachers }\end{array}$ & \multirow[t]{2}{*}{ Teachers agreed } \\
\hline & & & $\begin{array}{l}\text { In making decisions, the } \\
\text { principal respects each } \\
\text { teachers' opinion }\end{array}$ & \\
\hline & & \multirow[t]{2}{*}{$\begin{array}{lr}\text { Staff } & \text { Directing } \\
\text { and Development }\end{array}$} & $\begin{array}{l}\text { The principal helps to } \\
\text { develop professional } \\
\text { abilities through further } \\
\text { education, training, and } \\
\text { seminars }\end{array}$ & \multirow[t]{2}{*}{ Teachers agreed } \\
\hline & & & $\begin{array}{l}\text { The school principal } \\
\text { becomes tutor for } \\
\text { teachers to get } \\
\text { achievement }\end{array}$ & \\
\hline & & \multirow[t]{2}{*}{ School Evaluation } & $\begin{array}{lr}\text { Recognition } & \text { and } \\
\text { appreciation } & \text { of } \\
\text { teachers performance }\end{array}$ & \multirow[t]{2}{*}{ Teachers agreed } \\
\hline & & & $\begin{array}{lr}\text { The principal regularly } \\
\text { evaluates } & \text { the } \\
\text { performance } & \text { of } \\
\text { teachers } & \text { and } \\
\text { employees } & \\
\end{array}$ & \\
\hline & & Problem Solving & $\begin{array}{l}\text { When problems arises, } \\
\text { the school principal } \\
\text { conducts deliberations } \\
\text { to resolve them }\end{array}$ & Teachers agreed \\
\hline & & \multirow[t]{2}{*}{$\begin{array}{l}\text { Principal Integrity } \\
\text { Vision and Mission }\end{array}$} & $\begin{array}{l}\text { The principal can } \\
\text { estimate future school } \\
\text { needs }\end{array}$ & \multirow[t]{2}{*}{ Teachers agreed } \\
\hline & & & The principal & \\
\hline
\end{tabular}


Cucun Sunaengsih et.al., Principal Leadership in the Implementation of Effective School...

\begin{tabular}{|c|c|c|c|c|}
\hline \multirow[t]{3}{*}{ No } & \multirow[t]{3}{*}{ Variable } & \multirow[t]{3}{*}{ Indicator } & Sub. Indicator & \multirow[t]{3}{*}{ Conclusion } \\
\hline & & & $\begin{array}{l}\text { determines the ideals } \\
\text { and goals to be } \\
\text { achieved by the school }\end{array}$ & \\
\hline & & & $\begin{array}{l}\text { The principal provides } \\
\text { guidance to the } \\
\text { teachers }\end{array}$ & \\
\hline \multirow[t]{5}{*}{2} & \multirow[t]{5}{*}{$\begin{array}{l}\text { Effective } \\
\text { School } \\
\text { Management }\end{array}$} & Technology & $\begin{array}{l}\text { The use of technology in } \\
\text { the learning process }\end{array}$ & $\begin{array}{l}\text { Schools used existing } \\
\text { technologies such as } \\
\text { computers, and } \\
\text { laptops that were } \\
\text { available at school. }\end{array}$ \\
\hline & & & $\begin{array}{l}\text { The role of technology } \\
\text { in developing the } \\
\text { performance of school } \\
\text { personnel }\end{array}$ & $\begin{array}{l}\text { Technology was very } \\
\text { helpful in spreading } \\
\text { information and } \\
\text { managing files. In } \\
\text { providing information, } \\
\text { the principal just } \\
\text { needed to send a } \\
\text { message via an } \\
\text { application on his } \\
\text { hand phone or via } \\
\text { email. Also, emails } \\
\text { helped teachers } \\
\text { providing a report to } \\
\text { the principal and the } \\
\text { principal could } \\
\text { provide a report to } \\
\text { the central } \\
\text { management. }\end{array}$ \\
\hline & & Culture & $\begin{array}{l}\text { School culture has been } \\
\text { routinely carried out by } \\
\text { all school elements. }\end{array}$ & $\begin{array}{l}\text { Existed, besides the } \\
\text { Dhuha Prayer in } \\
\text { congregation, there } \\
\text { were also regular } \\
\text { gymnastics, reading } \\
\text { and cleaning } \\
\text { activities before the } \\
\text { lesson started. }\end{array}$ \\
\hline & & $\begin{array}{l}\text { System } \\
\text { Information }\end{array}$ & $\begin{array}{l}\text { Management of } \\
\text { information resources in } \\
\text { schools }\end{array}$ & $\begin{array}{ll}\text { Utilizing } & \text { existing } \\
\text { technology. } & \end{array}$ \\
\hline & & Organization & $\begin{array}{l}\text { Organizing teachers' } \\
\text { performance }\end{array}$ & 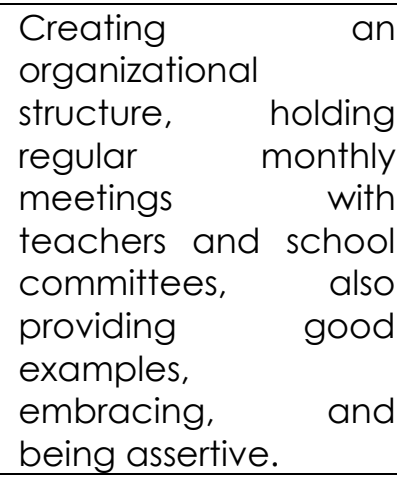 \\
\hline
\end{tabular}

Table 2 elaborates that: 
1. Principal leadership in implementing effective school management was inseparable from the use of technology, although there had only been a number of computers and laptops but principal was still trying to optimize the use of existing technology. Following are some efforts made by the principal:

a. Managing administration and academic data: managing of the curriculum implemented, compiling the teaching schedule in each subject, managing academic values that had been obtained by students and compiled student learning outcomes in each semester.

b. Managing the curriculum data, each class data, administration of subject taught, arrangement and division of schedules for each class, accumulation of student grades, predicate graduation requirements, school reports and statistical data and system administering.

c. Becoming a communication representative between the school community.

2. In the use of information system, even though the school had not had homemade applications yet, teachers could optimize every application available on a computer or laptop. Following are the information system available::

a. Information System related to staffing data on teachers and staff registered in the school. It consisted of curriculum vitae data, rank, position, address, working status, working hours, education history, career history, training history, attendance rate, salary info and others.

b. Information System related to financial management was used to manage school financial receipts and expenditures in order to facilitate the preparation of financial statements, which consisted of managing each revenue and expenditure made by schools, allocating budgets and monitoring the use of the budget to meet school needs, compiling financial accountability reports in the form of receipts and expenditures, recording each transaction made through transaction journals (acceptance journals, expenditure journals, and general journals), school accounting reports (general ledger and balance sheet reports), and all forms of system administration. In addition, there were also data on payment of education costs for students, which include school fee, development money, and others.

c. Community relations management system, which consisted of social media applications as means of communication between school communities. 
Cucun Sunaengsih et.al., Principal Leadership in the Implementation of Effective School...

3. The school culture has been described in the vision and mission through activities to create positive cultures in order to increase cognitive, affective, and psychomotor values outside of class hours. Following are the school culture applied:

a. Literacy activities, reading books in 15 minutes before learning begins.

b. Praying before and after learning.

c. Reading the short Qur'anic Letter after praying.

d. Saying hello to fellow friends and school teachers/employees.

e. Friday cleaning.

f. Weekly gymnastics.

g. Dhuha and Dzuhur prayers in congregation.

The school culture that was applied outside of lesson hours provided a positive output on the students' potential. The output was school achievement, especially student achievement which was characterized by the ability to compete with other students. This could be proven from several achievements that had been made in the last two years, namely obtaining the overall champion of scout at West Java Province level, became table tennis champion of the district level, and became first winner in the MTQ at the Sumedang Regency.

\section{DISCUSSION}

In terms of concepts it could be said that the school had implemented effective school management, because the school had tried to optimize the stages of interconnected school activities, namely planning, implementation and evaluation (Kompri, 2017). These stages greatly influenced the determination of school quality. To increase the principal' potential in planning school programs such as giving special guidance for students who lacked in certain subjects and guidance for students who took part in competition. Students' participation in the competition indirectly nurtured the character so that it was embedded in a happy soul and accustomed in taking a challenge, and this definitely showed a positive correlation to the lives of students in the future. In this case, the school sought to provide the best service to the school community through the utilization and development of existing potential.

The results of the research showed that the implementation of the principal leadership in effective school management was carried out optimally by the school. There was compatibility between aspects of leadership, management of productive schools, and the application of school culture. This was in accordance with Scheerens (Moerdiyanto, 2007) stating that effective schools had five important characteristics, such as: magnitude of the leadership influence, emphasis on achieving basic abilities, creation of comfortable environment, creation of high expectations on student achievement and creation of routine assessment regarding programs made for students. 
The implementation of principal' leadership and effective school management measured by 10 dimensions, namely concepts, design, requirements, procedures, impacts, technology, culture, organization, information system quality, leadership quality in including:

1. Concept, the concept was quite good, because it was in accordance with the concept of effective schools in general. The concept of effective schools was certainly oriented to the vision, mission and school goals that should be achieved as effectively as possible (Negulescu and Doval, 2014), which in its implementation relied on all forms of cooperation from all components of the school. Although it was not yet perfect, the school continued to try to optimize the achievement of effective school concept.

2. Design, the activities implementation was made in accordance with the concept of effective schools, namely through school programs that support the development of students' potential, such as extracurricular, etc. This effective school design was adjusted to the curriculum set by the government. It was also related to the design of character education applied by relevant schools which was also set by the government.

3. Requirements, the criteria for effective school determination were adjusted to the school's vision and mission.

4. Procedure, the carried out procedures were structured and systematic.
5. Impact, effective school management impacts could be seen and they provided positive results, one of which could be proven through the students' achievements.

6. Technology, the technology was optimized through all existing limitations. The technology was used for the learning process and staffing data management. In the implementation of effective school management, technology was a bridge of renewal in environmental change (Webster, 2017). It did not matter how adequate the technology facilities were, but the principal ability in managing the limitations would greatly affect the use of the technology itself in the school.

7. Culture, the culture that had been implemented was good, so that it could improve the quality of educators.

8. Organizations, the schools ran structured organizational systems. The principal could arrange and adjust the teachers' duties in the division of tasks according to the abilities of the teacher.

9. Information system quality, although the schools did not have a homemade application, but the use and utilization of the information system were optimized.

10. Leadership quality, leadership ran by schools through coordination between school principal and teachers to develop the students' potential and the surrounding community. 
Cucun Sunaengsih et.al., Principal Leadership in the Implementation of Effective School...

\section{CONCLUSION}

The principal had implemented effective school management. This was proved through the implementation of the principal leadership in creating culture and combining leadership concepts and technology with school management. However, the leadership of the school principal applied was not fully in accordance with effective school management indicators, namely those that were oriented towards achieving goals with the use of capable technology. The use of technology was not yet maximized, which could be seen from the limited and simple use of technology in completing tasks. With these findings, it is expected that there is an applicative model of principal leadership in realizing effective school management. Thus, the limitations of the school do not become a barrier in reaching the achievement and quality mandated by the Indonesian education system.

\section{REFERENCES}

Al-Momani, M., Allouh, Z. and Al-homran, M. (2012). Teachers Implementation of Effective Classroom Management from Vocational Education Students' Perspectivesa. International Journal of Education, 4(3), pp. 137-146.

Asmani, M.J. (2014). Tips Membangun Komunitas Belajar di Sekolah. Jogjakarta: Diva Press.

Bergeron, B. (2011). Essentials of Knowledge Management Management.

Brooks, J. M. (2005). Leadership can be taught: A bold approach for a complex world.Christian Education
Journal, 4(2), pp. 367-395.

Chow, B. A. S., Ph, D. and Learning, $O$. (2013). Merging Design Principles, Systemic Change and Leadership Thinking. TechTrends, 57(5).

Dreiss, L. M. et al. (2017). Adaptive Management as an Effective Strategy: Interdisciplinary Perceptions for Natural Resources Management. Environmental Management. Springer US, pp. 218-229.

Ibrahim, B. (2016). Keefektifan Organisasi Dalam Pemberdayaan Sekolah. Jurnal Tarbawi, 2 (1),53-63.

Komariah, A. dan Satori, D. (2010). Metodologi Penelitian Kualitatif. Bandung: Alfabeta.

Kompri. (2017). Standarisasi Kompetensi Kepala Sekolah. Jakarta: Kencana

Krug, D. H. (2004). Leadership and Research: Reimagining Electronic Technologies for Supporting Learning Through the Visual Arts.Studies in Art Education a Journal of Issues and Research, 46(1), pp. 3-5.

Kwek, L. C., Lau, T. C. and Tan, H. P. (2010). Education Quality Process Model and Its Influence on Students ' Perceived Service Quality.International Journal of Business and Management, 5(8), pp. 154-165.

Lessa, B. D. S., Spier, K. F. and Felipe, L. (2018). Barriers for Sustainability in Management Schools: A Bourdieusian Explanation.RAEP, 19(3).

Moerdiyanto. (2007). Manajemen Sekolah Indonesia Yang Efektif Melalui Penerapan Total Quality Management. Online. https://staff.uny.ac.id/sites/default/file s/penelitian/Drs.\%20Moerdiyanto,\%20E FEKTIF.pdfdiakses pada tanggal 08 Mei 2018).

Mulyana, D. (2008). Metodologi Peneltian Kualitatif. Bandung: PT. Remaja

Negulescu, O. and Doval, E. (2014). The quality of decision making process related to organizations 
effectiveness.Procedia Economics and Finance. Elsevier B.V., 15(14), pp. 858-863.

Nurbaya, S., Harun, Z.C., \& Djaelani. (2015). Gaya Kepemimpinan Kepala Sekolah Dalam Meningkatkan Kinerja Guru Pada Sd Negeri Lambaro Angan. Jurnal Administrasi Pendidikan,3 (2), 116-127.

Pidarta, M. (2009). Supervisi Pendidikan Kontekstual. Jakarta: PT. Rineka Cipta.

Rahmat. (2009). Penelitian Kualitatif. Equilibrium Journal, 9(5), 1-8.I

Salmagundi. (2015). Weatherhead School of Management Case Western Reserve University.Accounting Historians Journal, 12(19), pp. 129-138.

Satriadi. (2016). Pengaruh Kepemimpinan Kepala Sekolah Terhadap Kinerja Guru. Jurnal Benefita, 1 (3),(123-133).

Smith, B. H. (2013). School-based Character Education in The United States.in Childhood Education, pp. 350-355.

Suryosubroto, B. (2010). Manajemen Pendidikan di Sekolah. Jakarta: PT. Rineka Cipta.

Tim Pengembang IImu Pendidikan FIP-UPI. (2007). IImu dan aplikasi pendidikan. Bandung: PT. Imperial Bhakti Utama.

Umaedi. (1999). Manajemen Pendidikan Mutu Berbasis Sekolah: Sebuah Pendekatan untuk Meningkatkan Mutu. Jakarta: Depdiknas.

Webster, M. D. (2017). Philosophy of Technology Assumptions in Educational Technology Leadership.Educational Technology \& Society, 20(1), pp. 25-36. 